\title{
Pengaruh Pengendalian Internal dan Kompensasi Terhadap Kinerja Pengrajin Dengan Motivasi Sebagai Variabel Intervening (Survei pada Pengrajin Batik di Kota Jambi)
}

\author{
Netty Herawaty, Rizky Yulisari \\ Universitas Jambi \\ Correspondence email: netherawaty@gmail.com, rizkiyulisari@gmail.com
}

\begin{abstract}
The purpose of this study was to determine and analyze whether there is an influence of internal control and compensation for the performance of craftsmen, to find out and analyze whether there is an influence of internal control and compensation for motivation, to know and analyze whether there is a motivational influence on the performance of craftsmen and to know and analyze whether there is an influence of internal control and compensation for the motivation and performance of craftsmen. This study uses a multiple regression analysis tool. This study uses primary data. Respondents in this study were batik craftsmen. The results of this study indicate that internal control, compensation and motivation simultaneously show a significant influence on the performance of craftsmen. The influence of internal control and compensation is directly greater than the indirect effect on performance through work motivation, so it can be concluded that work motivation does not become a variable mediating between internal control and compensation for the performance of batik craftsmen.
\end{abstract}

keyword : internal control, compensation, motivation, dan performance

\section{PENDAHULUAN}

Krisis ekonomi yang terjadi di Indonesia sejak beberapa waktu yang lalu, dimana banyak usaha berskala besar yang mengalami stagnasi bahkan terhenti aktifitasnya, sektor Usaha Kecil dan Menengah (UKM) terbukti lebih tangguh dalam mengahadapi krisis tersebut. Pengalaman yang telah dihadapi oleh Indonesia selama krisis, kiranya tidak berlebihan apabila pengembangan sektor swasta difoluskan pada UKM, terlebih lagi unit usaha ini seringkali terabaikan hanya karena hasil produksinya dalam skala kecil dan belum mampu bersaing dengan unit usaha lainnya. Produktivitas UKM/IKM harus terus ditingkatkan dengan cara mempekerjakan pengrajin yang memiliki kualitas dan kinerja yang baik. Perusahaan harus mampu memberikan motivasi kepada karyawannya agar karyawan tersebut dapat bekerja dengan sungguhsungguh sehingga nantinya akan mencapai tujuan perusahaan. (Jupran, 2015).

UKM harus memiliki pengendalian internal yang baik. Perusahaan menerapkan sistem pengendalian intern dengan alasan untuk membantu pimpinan agar perusahaan dapat mencapai tujuan dengan efisien. Menurut Mulyadi (2001), sistem pengendalian intern meliputi struktur organisasi, metode dan ukuranukuran yang dikoordinasikan untuk menjaga kekayaan organisasi, mengecek ketelitian dan keandalan data akuntansi, mendorong efisiensi dan mendorong dipatuhinya kebijakan manajemen. Kinerja karyawan merupakan hal penting dalam meningkatkan produktivitas karyawan tersebut. Perusahaan meningkatkan kinerja karyawan harus dapat mengetahui faktor faktor yang dapat mempengaruhi kinerja. Faktor-faktor tersebut diantaranya adalah pelatihan dan motivasi terhadap karyawan. Menurut Agusta dan Madiono (2013) untuk memecahkan masalah terkait dengan peningkatkan kinerja karyawan ada beberapa kemungkinan yang dapat dilakukan oleh perusahaan antara lain melalui pemberian motivasi dan pelatihan kerja.

Motivasi kepada karyawan atau seseorang tentu saja mempunyai tujuan antara lain: mendorong semangat dan gairah karyawan, meningkatkan moral dan kepuasan kerja karyawan, meningkatkan produktivitas kerja karyawan, mempertahankan loyalitas dan kestabilan karyawan, meningkatkan kedisiplinan dan menurunkan tingkat absensi karyawan, menciptakan suasana dan hubungan kerja yang baik, meningkatkan kreativitas dan partisipasi karyawan, meningkatkan kesejahterahan karyawan, mempertinggi rasa tanggung jawab karyawan terhadap tugas dan pekerjaannya. (Agusta dan Madiono, 2013). Para karyawan akan lebih termotivasi untuk melakukan tanggung jawab atas pekerjaan mereka apabila perusahaan mengerti dan memperhatikan betul akan kebutuhan para karyawan yang pada dasarnya adalah mereka bekerja untuk mendapatkan uang, dalam hal ini berbentuk gaji. Kompensasi adalah semua 
pendapatan yang berbentuk uang, barang langsung atau tidak langsung yang diterima karyawan sebagai imbalan atas jasa yang diberikan kepada perusahaan (Hasibuan, 2010).

Kerajinan batik salah satu produk ekonomi kreatif handalan dari Kota Jambi. Kerajinan batik merupakan salah satu sektor industri kreatif yang berpotensi dalam memberikan kontribusi dan solusi pada persoalan-persoalan lingkungan, sosial dan ekonomi bangsa. Pada sentra kerajinan batik di wilayah Seberang Kota Jambi hanya sekitar 30 persen dari 168 Industri Kecil Menengah (IKM) yang khusus memproduksi batik khas daerah Jambi yang masih beroperasi dalam memproduksi batik Jambi, sisanya gulung tikar. Hal ini merupakan fenomena yang menunjukkan bahwa industri batik Jambi mengalami penurunan produktivitas dan pangsa pasar. Penurunan produktivitas akan menyebabkan berkurangnya pangsa pasar karena ketidakmampuan memenuhi permintaan pasar, menurunnya kesejahteraan perajin dan itu berarti masih rendahnya daya saing IKM batik (Raf, 2012).

Industri batik di Kota Jambi saat ini sangat banyak terutama di daerah Kota Jambi Seberang. Motif batik Jambi juga sangat beragam. motif batik daerah Jambi mempunyai ciri-ciri khas tersendiri dan telah berkembang sedemikian rupa hingga dikenal oleh masyarakat Indonesia dan mancanegara. Batik Jambi sekarang telah menjadi salah satu komoditi unggulan daerah Jambi, selain telah dapat membantu pemerintah daiam menanggulangi pengangguran, juga telah mendapat penghargaan baik dari masyarakat daerah maupun tingkat nasional. Batik Jambi telah beberapa kali mendapat penghargaan di tingkat nasional antara lain yaitu upakarti tahun 1988 atas nama "Batik Relita", Upakarti tahun 1990 atas nama "Batik Nova", Upakarti tahun 1993 atas nama Ketua Tim Penggerak PKK Propinsi Jambi, Upakarti tahun 1994 atas nama "Batik Mawarda".

Munculnya industri tekstil bermotif batik, disatu sisi merupakan penunjang atas keberadaan dan pelestarian motif batik tradisional itu sendiri, karena semakin banyak yang menerapkan motif batik tradisional berarti pelestarian, terutama dari segi motif dapat dipertahankan tetapi dari segi kehidupan industri batik tradisional justru sebaliknya, karena tekstil bermotif batik yang diproduksi secara besarbesaran akan menjatuhkan harga batik tradisional disamping mempercepat tingkat kejenuhan motif tersebut dimata konsumen. Upaya percepatan pengembangan kerajinan batik merupakan persoalan yang harus diperhatikan, sehingga dalam pembinaan dan pengembangan industri batik tradisional, baik motif maupun industri batiknya sendiri, diharapkan dapat terus maju bersama dan saling mendukung. (Idamariyanti, 2011)

Permintaan akan batik Jambi di pasaran cukup tinggi namun hasil produksi tidak seimbang dengan permintaan pasar, bahkan beberapa produk batik Jambi yang beredar di pasaran diproduksi di Jawa. Hal tersebut dirasakan akan merugikan masyarakat Jambi, karena industri batik Jambi adalah industri yang cukup potensial dari segi ekonomi untuk meningkatkan kesejahteraan masyarakat, (Yuafni, 2012). Ketua Dewan Kerajinan Nasional Daerah (Dekranasda) Provinsi Jambi, Hj. Sherrin Tharia Zola menghimbau para perajin batik jambi terus melatih diri dan cari inovasi baru agar menghasilkan karya-karya yang lebih bagus lagi dan pengrajin batik untuk terus berlatih agar dapat menghasilkan karya baru serta bermutu. (Idamariyanti, 2011). Penelitian ini adalah untuk mengetahui dan menganalisis apakah ada pengaruh pengendaliam internal dan kompensasi terhadap motivasi (survei pada pengrajin batik di Kota Jambi), pengaruh motivasi terhadap kinerja pengrajin (survei pada pengrajin batik di Kota Jambi), pengaruh pengendaliam internal dan kompensasi terhadap kinerja pengrajin (survei pada pengrajin batik di Kota Jambi, dan pengaruh pengendalian internal dan kompensasi terhadap kinerja pengrajin melalui motivasi (survei pada pengrajin batik di Kota Jambi)

\section{Tinjauan Pustaka}

Kementerian yang ada di Indonesia menerapkan definisi yang berbeda untuk UMKM. Perbedaan tersebut dapat dilihat dari kriteria yang ditetapkan oleh masing-masing instansi. (1) usaha kecil menurut Departemen Perindustrian adalah perusahaan yang mempekerjakan 5-10 karyawan, (2) usaha kecil menurut Departemen Perdagangan adalah perusahan yang memiliki modal minimal Rp.500.000, (3) usaha kecil menurut Departemen Pertanian adalah perusahaan yang memiliki lahan minimal 2 Hektar. Masing-masing departemen mendifinisikan sesuai dengan lingkup departemen terkait.

Menurut Undang-Undang No. 20 tahun 2008, usaha kecil adalah usaha ekonomi produktif yang berdiri sendiri, yang dilakukan oleh orang perorangan atau badan usaha yang bukan merupakan anak 
perusahaan atau bukan cabang perusahaan yang dimiliki, dikuasai, atau menjadi bagian baik langsung maupun tidak langsung dari usaha menengah atau usaha besar. Usaha Menengah adalah usaha ekonomi produktif yang berdiri sendiri, yang dilakukan oleh orang perseorangan atau badan usaha yang bukan merupakan anak perusahaan atau cabang perusahaan yang dimiliki, dikuasai, atau menjadi bagian baik langsung maupun tidak langsung dengan usaha kecil atau dengan usaha besar dengan jumlah kekayaan bersih atau hasil penjualan tahunan.

Apabila dilihat dari kepemilikan aset, pemerintah memberikan batasan tentang Usaha kecil yaitu: (1) memiliki kekayaan bersih (aset) bersih lebih dari Rp 50 juta sampai dengan paling banyak Rp 500 juta tidak termasuk tanah dan bangunan tempat usaha, (2), hasil penjualan tahunan lebih dari Rp 300 juta sampai dengan Rp 2,5 milyar, (3) milik warganegara Indonesia, dan (4) berdiri sendiri, bukan merupakan anak perusahaan atau cabang perusahaan. Sementara Usaha Menengah adalah: Kriteria Usaha Menengah adalah sebagai berikut: (1) a. memiliki kekayaan bersih lebih dari Rp500.000.000,00 (lima ratus juta rupiah), (2) sampai dengan paling banyak Rp10.000.000.000,00 (sepuluh milyar rupiah) tidak, (3) termasuk tanah dan bangunan tempat usaha; atau memiliki hasil penjualan tahunan lebih dari Rp2.500.000.000,00 (dua milyar lima ratus juta rupiah) sampai dengan paling banyak Rp50.000.000.000,00 (lima puluh milyar rupiah).

Berdasarkan perkembangan UKM di Indonesia Dibedakan Menjadi 4 Kriteria (UU tahun 2008) yaitu

a. Livelihood Activities, merupakan Usaha Kecil Menengah yang digunakan sebagai kesempatan kerja untuk mencari nafkah, yang lebih umum dikenal sebagai sektor informal. Contohnya adalah pedagang kaki lima.

b. Micro Enterprise, merupakan Usaha Kecil Menengah yang memiliki sifat pengrajin tetapi belum memiliki sifat kewirausahaan.

c. Small Dynamic Enterprise, merupakan Usaha Kecil Menengah yang telah memiliki jiwa kewirausahaan dan mampu menerima pekerjaan subkontrak dan ekspor

d. Fast Moving Enterprise, merupakam Usaha Kecil Menengah yang telah memiliki jiwa kewirausahaan dan akan melakukan transfer

Pengendalian diperlukan untuk mencapai tujuan perusahaan. Sejalan dengan semakin luas dan kompleksnya perusahaan, manajemen perusahaan dihadapkan pada keterbatasan kemampuan untuk mengawasi dan mengendalikan operasi perusahaan. Keadaan ini menyebabkan manajemen melimpahkan tanggung jawab dan wewenang. Untuk memastikan bahwa kegiatan perusahaan telah sesuai dengan kebijakan dan prosedur maka diperlukan sistem pengendalian intern. (Adisetiawan dan Surono, 2016)

Pengertian internal contrtol (Whittington, 2001), Internal control is broadly defined as a process, effected by an entity's board of directors, management, and other personnel, designed to provide reasonable assurance regarding the achievement of objectives in the following categories: effectiveness and efficiency of operations, reliability of financial reporting, and compliance with applicable laws and regulations. Arens, et. al (2014) mengemukakan elemen struktur pengendalian intern sebagai berikut A company's internal control include five categories of policies and procedures that management design and implement to provide reasonable assuarance that management's control objective will be met. These are called the components of internal control are: (1) the Control Environment; (2) Risk Assessment; (3) Control Activities; (4) Information and Communication; (5) Monitoring. Baik buruknya struktur pengendalian intern akan memberikan pengaruh yang besar terhadap: keamanan harta perusahaan, dapat dipercayai atau tidaknya laporan keuangan perusahaan, lama atau cepatnya proses pemeriksaan akuntan, tinggi atau rendahnya auditfee, jenis opini yang akan diberikan akuntan publik.

Selanjutnya Arens, et. al (2014) mengungkapkan pentingnya Internal control sebagai berikut:

a. The Scope and size of the business entity has become so complex and wide spread that management must rely on numerous reports and analyses to effectively control operations.

$b$. The check and review inherent in a good system of internal control affords protection against human weaknesses and reduces the possibility that errors or irregularities will occur, It is impracticable for auditors to make audits of most companies within economic fee limitations without relying on the client's system of internal control 
Pengendalian intern memiliki tujuan untuk memberikan keyakinan memadai dalam pencapaian tiga golongan tujuan: keandalan pelaporan keuangan, efektifitas dan efisiensi operasi entitas, kesesuaian dengan undang-undang dan peraturan yang berlaku (Jusuf, 2014). Setiap kegiatan yang dilakukan oleh seseorang didorong oleh suatu kekuasaan dalam diri orang tersebut, kekuatan pendorong inilah yang disebut motivasi. Suharto dan Cahyono (2005) mengatakan bahwa motivasi adalah "...getting a person to exert a high degree of effort..."yang artinya adalah "motivasi membuat seseorang untuk bekerja lebih berprestasi". Menurut Luthans (2006) motivasi adalah proses sebagai langkah awal seseorang melakukan tindakan akibat kekurangan secara fisik dan psikis atau dengan kata lain adalah suatu dorongan yang ditunjukan untuk memenuhi tujuan tertentu. Secara garis besar, teori motivasi dikelompokkan ke dalam tiga kelompok yaitu teori motivasi dengan pendekatan isi/kepuasan (content theory), teori motivasi dengan pendekatan proses (process theory) dan teori motivasi dengan pendekatan penguat (reinforcement theory).

Motivasi adalah keinginan yang terdapat pada seorang individu yang merangsang untuk melakukan tindakan Terdapat dua metode dalam motivasi, metode tersebut adalah metode langsung dan metode tidak langsung. (Hasibuan, 2010)

a. Metode Langsung (Direct Motivation), merupakan motivasi materiil atau non materiil yang diberikan secara langsung kepada seseorang untuk pemenuhan kebutuhan dan kepuasannya. Motivasi ini dapat diwujudkan misalnya dengan memberikan pujian, penghargaan, bonus dan piagam.

b. Metode Tidak Langsung (Indirect Motivation), merupakan motivasi yang berupa fasilitas dengan maksud untuk mendukung serta menunjang gairah kerja dan kelancaran tugas.

Menurut Hasibuan (2010), Kompensasi adalah semua pendapatan yang berbentuk uang, barang langsung atau tidak langsung yang diterima karyawan sebagai imbalan atas jasa yang diberikan kepada perusahaan. Kompensasi sesungguhnya merupakan pengertian luas dari pengupahan". Kompensasi mencakup pula tunjangan-baik tunjangan berbentuk uang maupun non uang-selain gaji atau upah yang diterima setiap bulan. Menurut Jupran (2015), kompensasi finansial dan kompensasi non finansial. Kompensasi finansial terdiri dari kompensasi finansial langsung dan kompensasi finansial tidak langsung. Kompensasi finansial langsung yaitu Upah, Gaji, insentif. Sedangkan kompensasi finansial tidak langsung yaitu bayaran diluar jam kerja (liburan, hari besar, cuti) dan pemberian fasilitas (kendaraan, ruang kantor, tempat parkir). Kompensasi non finansial berkaitan dengan pekerjaan (pekerjaan yang menarik, kesempatan untuk berkembang, pelatihan, dll) dan berkaitan dengan lingkungan pekerjaan (kondisi kerja mendukung, pembagian kerja)

Menurut Hasibuan (2010), tujuan pemberian kompensasi (balas jasa) antara lain adalah:

1. Ikatan Kerja Sama

Pemberian kompensasi terjalinlah ikatan kerja sama formal antara majikan dengan karyawan. Karyawan harus mengerjakan tugas-tugasnya dengan baik, sedangkan pengusaha/majikan wajib membayar kompensasi sesuai dengan perjanjian yang disepakati.

2. Kepuasan Kerja

Balas jasa, karyawan akan dapat memenuhi kebutuhan-kebutuhan fisik, status sosial, dan egoistiknya sehingga memperoleh kepuasan kerja dari jabatannya.

3. Pengadaan Efektif

Jika program kompensasi ditetapkan cukup besar, pengadaan karyawan yang qualified untuk perusahaan akan lebih mudah.

4. Motivasi

Jika balas jasa yang diberikan cukup besar, manajer akan mudah memotivasi bawahannya.

5. Stabilitas Karyawan

Program kompensasi atas prinsip adil dan layak serta eksternal konsistensi yang kompentatif maka stabilitas karyawan lebih terjamin karena turn-over relatif kecil.

6. Disiplin

Pemberian balas jasa yang cukup besar maka disiplin karyawan semakin baik. Mereka akan menyadari serta mentaati peraturan-peraturan yang berlaku.

7. Pengaruh Serikat Buruh 
Program kompensasi yang baik pengaruh serikat buruh dapat dihindarkan dan karyawan akan berkonsentrasi pada pekerjaannya.

8. Pengaruh Pemerintah

Jika program kompensasi sesuai dengan undang-undang perburuhan yang berlaku (seperti batas upah minimum) maka intervensi pemerintah dapat dihindarkan.

Sistem pembayaran kompensasi yang umum diterapkan adalah (Hasibuan, 2010):

1. Sistem Waktu

Sistem waktu, besarnya kompensasi (gaji, upah) ditetapkan berdasarkan standar waktu seperti jam, minggu, atau bulan.

2. Sistem Hasil (Output)

Sistem hasil, besarnya kompensasi/upah ditetapkan atas kesatuan unit yang dihasilkan pekerja, seperti per potong, meter, liter, dan kilogram.

3. Sistem Borongan

Sistem borongan adalah suatu cara pengupahan yang penetapan besarnya jasa didasarkan atas volume pekerjaan dan lama mengerjakannya.

Menurut Mangkunegara (2015) kinerja karyawan dapat dinilai dengan beberapa indikator yaitu: Quality of work yaitu kualitas kerja ini akan dicapai berdasarkan kesesuaian dan kesiapan. Quantity of Work (kuantitas kerja) yaitu jumlah kerja yang dilakukan dalam suatu periode waktu yang ditentukan, Job Knowledge (pengetahuan pekerjaan) yaitu luasnya pengetahuan mengenai pekerjaan dan keterampilan, Creativeness (kreatifitas) yaitu keaslian gagasan-gagasan yang dimunculkan dan tindakan-tindakan untuk menyelesaikan persoalan-persoalan yang timbul, Cooperative (kerjasama) yaitu kesadaran untuk bekerja sama dengan orang lain, Initiative (inisiatif) yaitu keaslian ide-ide yang disampaikan sebagai program organisasi dimasa yang akan datang, Dependerability (ketergantungan) yaitu kesadaran dapat dipercaya dalam hal kehadiran dan penjelasan kerja, Personal Quality (kualitas personil) yaitu menyangkut kepribadian kepemimpinan, kemampuan dan integritas pribadi. (Adisetiawan dan Surono, 2011)

Wirausahawan adalah seseorang yang memiliki kemampuan dalam menggunakan dan mengkombinasikan sumber daya seperti keuangan, bahan mentah, tenaga kerja, keterampilan dan informasi untuk menghasilkan produk baru, proses produksi baru, bisnis baru dan organisasi usaha baru. Menurut bahasa Indonesia, kata wirausaha merupakan gabungan kata wira (gagah berani,perkasa) dan usaha. Jadi, wirausaha berarti orang yang gagah berani atau perkasa dalam usaha. Entrepreneur adalah sebuah proses "destruktif yang kreatif", dimana produk-produk atau metode produksi yang sudah ada dihancurkan dan diganti dengan yang baru. Oleh karena itu entrepreneurship berkaitan dengan penemuan, pendayagunaan peluang-peluang yang menguntungkan, dengan kata lain fungsi spesifik dari entrepreneur adalah inovasi. Inovasi berarti penciptaan nilai sebagai sumber keunggulan kompetitif, tanpa inovasi cara/metode baru tidak akan pernah ditemukan. Para entrepreneur akan terus melakukan ekspansi memperluas daerah pemasaran, menambah jumlah pelanggan meningkatkan penjualan dan laba. Pengrajin ialah orang yang pekerjaannya membuat barang-barang kerajinan. Ada pengrajin ukir, pengrajin batik, pengrajin wayang, pengrajin perak, dan sebagainya. Barang-barang kerajinan itu tidak dibuat dengan mesin, melainkan dengan tangan, sehingga sering disebut barang kerajinan tangan.

\section{METODE PENELITIAN}

Penelitian ini menggunakan variabel independen pengendalian internal, kompensasi..Variabel dependen kinerja dan variabel intervening motivasi. Jenis data yang digunakan adalah data primer yang diperoleh dari kuesioner yang disebarkan ke para pengrajin batik di Kota Jambi. Populasi penelitian ini adalah para pengrajin batik yang ada di Kota Jambi. Pengambilan sampel dengan menggunakan purposive sampling dimana yang akan dijadikan sampel adalah para pengrajin batik yang ada di Kecamatan Danau Teluk dan Kecamatan Pelayangan. Peneliti mengambil responden di Kecamatan Danau Teluk dan Kecamatan Pelayangan karena kedua kecamatan ini adalah kecamatan yang terletak di Seberang Kota Jambi yang memiliki pengrajin batik yang lebih dominan dibandingkan dengan kecamatan lain. Jumlah sampel yang akan diambil yaitu responden yang berada di Kecamatan Danau Teluk yaitu ada lima kelurahan yaitu Kelurahan/Desa Ulu Gedong, Kelurahan/Desa Olak Kemang, Kelurahan/Desa Tanjung Pasir, 
Kelurahan/Desa Tanjung Raden dan Kelurahan/Desa Pasir Panjang dan Kecamatan Pelayangan ada enam kelurahan yaitu Kelurahan/Desa Arab Melayu, Kelurahan/Desa Mudung Laut, Kelurahan/Desa Jelmu, Kelurahan/Desa Tengah, Kelurahan/Desa Tahtul Yaman dan Kelurahan/Desa Tanjung Johor. Jumlah sampel yang akan diambil sejalan dengan Sekaran (2000), pada penelitian multivariate (termasuk analisis regresi multivariate) ukuran sampel harus beberapa kali lebih besar (10 kali) dari jumlah variabel yang akan dianalisis. Jumlah variabel yang diteliti sebanyak 4 variabel berarti jumlah sampel minimal yaitu 40 orang responden.

Instrumen yang valid dan reliabel dalam mengumpulkan data sangat diperlukan untuk mendapatkan hasil penelitian yang juga valid dan reliabel. Instrumen valid dapat mengungkapkan sesuatu yang menjadi sasaran pokok pengukuran. Pengujian validitas instrumen dilakukan dengan menggunakan uji Pearson Product Moment Coefficient of Corelation. Instrumen akan dinyatakan valid jika memiliki tingkat signifikan dibawah 5\%. Sedangkan Indikator untuk uji reliabilitas adalah Cronbach Alpha, apabila nilai Cronbach Alpha > 0.6 menunjukkan instrumen yang digunakan reliabel (Ghozali, 2002).

Penelitian ini menggunakan alat analisis regresi berganda dengan terlebih dahulu mengkonversikan skala ordinal ke skala interval melalui metode interval berurutan (Method of successive interval). Asumsi klasik yang digunakan dalam penelitian ini adalah uji normalitas, asumsi Multikolinearitas, Heteroskedastisitas.

1) Uji t

Pengujian hipotesis diuji dengan menggunakan uji T dan uji F:

Uji t dimaksudkan untuk menguji pengaruh variabel independen terhadap perubahan variabel dependen secara parsial. Kriteria pengujian dengan menggunakan uji t adalah sebagai berikut:

- Jika t hitung > t tabel dengan tingkat signifikansi 5\% ( $\rho$ value $<0.05)$, maka $\mathrm{H}_{0}$ ditolak dan $\mathrm{H}_{\mathrm{a}}$ diterima

- Jika t hitung < t tabel dengan tingkat signifikansi 5\% ( $\rho$ value $<0.05)$, maka $\mathrm{H}_{0}$ diterima dan $\mathrm{H}_{\mathrm{a}}$ ditolak

2) Uji F

Uji f dimaksudkan untuk menguji pengaruh variabel independen terhadap perubahan variabel dependen secara menyeluruh (simultan). Kriteria pengujian dengan menggunakan uji f adalah sebagai berikut:

- Jika $\mathrm{f}$ hitung $>\mathrm{f}$ tabel dengan tingkat signifikansi 5\% ( $\rho$ value $<0.05$ ), maka $\mathrm{H}_{0}$ ditolak dan $\mathrm{H}_{\mathrm{a}}$ diterima.

- Jika f hitung < $\mathrm{f}$ tabel dengan tingkat signifikansi 5\% ( $\rho$ value $<0.05$ ), maka $\mathrm{H}_{0}$ diterima dan $\mathrm{H}_{\mathrm{a}}$ ditolak.

Persamaan yang digunakan dalam penelitian:

Model 1:

$M=\alpha_{1}+\beta_{1} X_{1}+\beta_{2} X_{2}+\varepsilon$

$\mathrm{Y}=\alpha_{2}+\beta_{3} \mathrm{M}+\varepsilon$

Model 2:

$M=\alpha_{1}+\beta_{1} X_{1}+\beta_{2} X_{2}+\varepsilon$

$Y=\alpha_{2}+\beta_{3} \mathrm{M}+\varepsilon$

$Y=\alpha_{3}+\beta_{4} X_{4}+\beta_{5} X_{5}+\varepsilon$

Model di atas dapat digabung menjadi:

$M=\alpha_{1}+\beta_{1} X_{1}+\beta_{2} X_{2}+\varepsilon$

$Y=\alpha_{2}+\beta_{2} M+\beta_{3} X_{3}+\beta_{4} X_{4}+\varepsilon$

Keterangan: $Y=$ Kinerja pengrajin; $\alpha=$ Koefisien konstanta; $\beta=$ koefisien variabel independen; $X_{1 i t}=$ pengendalian internal; $X_{2 i t}=$ kompensasi; $\mathrm{M}=$ Motivasi (variabel intervening); $\varepsilon=$ Error Term

\section{Hipotesis}

$\mathrm{H}_{1}$ : Pengendaliam internal dan kompensasi berpengaruh terhadap motivasi (survei pada pengrajin batik di Kota Jambi)

$\mathrm{H}_{2}$ : Motivasi berpengaruh terhadap kinerja pengrajin (survei pada pengrajin batik di Kota Jambi) 
$\mathrm{H}_{3}$ : Pengendaliam internal dan kompensasi berpengaruh terhadap kinerja pengrajin (survei pada pengrajin batik di Kota Jambi)

$\mathrm{H}_{4}$ : Pengendalian internal dan kompensasi terhadap kinerja pengrajin melalui motivasi (survei pada pengrajin batik di Kota Jambi)

\section{HASIL DAN PEMBAHASAN}

Penelitian ini menggunakan data primer yang diperoleh dengan menggunakan instrumen penelitian berupa kuesioner berisi pertanyaan yang telah dikirimkan kepada seluruh responden yaitu pemilik dan perajin batik di Kota Jambi. Setiap responden menjawab tiga puluh enam pertanyaan (36) pertanyaan terdiri atas tigabelas (13) pertanyaan terkait dengan pengendalian internal, tujuh (7) pertanyaan terkait dengan kompensasi, delapan (8) pertanyaan terkait dengan motivasi dan delapan (8) pertanyaan terkait dengan kinerja pengrajin. Berdasarkan hasil uji $\mathrm{f}$ terlihat bahwa nilai f hitung sebesar 6,321 dengan tingkat signifikansi 0,004 dengan menggunakan tingkat signifikansi 5\% atau 0,05 maka $\mathrm{H}_{1}$ diterima. Hal ini dibuktikan dengan nilai signifikansi yang lebih kecil dari 0,05, ini berarti bahwa secara simultan penggunaan Pengendalian internal dan Kompensasi terhadap Motivasi. Penelitian ini sejalan dengan penelitian sebelumnya Mahesa (2010), Agusta dan Madiono (2013) yang mengatakan Pengendalian Internal dan kompensasi berpengaruh terhadap motivasi.

Pengujian Pengendaian Internal dan Kompensasi terhadap Motivasi pengrajin menghasilkan nilai statistik t sebesar 3,245 dengan tingkat signifikansi $p$-value sebesar 0.002, oleh karena $p$-value lebih kecil dari 0,05 maka $\mathrm{H}_{2}$ diterima yang berarti bahwa Pengendalian Internal berpengaruh signifikan terhadap Motivasi. Penelitian ini sejalan dengan penelitian sebelumnya Mariani (2013), yang mengatakan bahwa pengendalian internal berpengaruh terhadap Motivasi. Simpulan bahwa pengendalian internal yang baik akan memberikan kontribusi baik dalam menciptakan suasana kerja sehingga dapat mendorong karyawan untuk meningkatkan motivasi kerjanya. Pengujian variabel Kompensasi terhadap Motivasi menghasilkan nilai statistik t sebesar -1,198 dengan tingkat signifikansi $p$-value sebesar 0.239 . Oleh karena nilai $p$-value lebih besar dari 0,05 maka $\mathrm{H}_{3}$ ditolak yang berarti bahwa Kompensasi tidak berpengaruh signifikan terhadap Motivasi

Pengujian variabel Pengendalian Internal dan Kompensasi terhadap Kinerja Pengrajin dengan Motivasi sebagai variabel intervening menghasilkan nilai statistik t sebesar 2,929 dengan tingkat signifikansi p-value sebesar 0.006 adalah signifikan, dengan demikian hipotesis 4 yang menyatakan Pengendalian Internal dan Kompensasi terhadap Kinerja Pengrajin dengan Motivasi sebagai variabel intervening dapat diterima. Pengujian pengaruh langsung untuk pengujian koefisien jalur antara pengendalian internal terhadap kinerja pengrajin sebesar 0,303, sedangkan pengaruh tidak langsung antara pengendalian initernal melalui motivasi terhadap kinerja pengrajin yaitu $0,464 \times 0,439=0,203$. Berdasarkan hasil perhitungan tersebut dapat diketahui bahwa pengaruh langsung sebesar 0,303 dan pengaruh tidak langsung sebesar 0,203 yang berarti bahwa nilai perhitungan langsung lebih besar dibandingkan pengaruh tidak langsung, hasil ini menunjukkan bahwa secara tidak langsung pengendalian internal melalui motivasi tidak mempunyai pengaruh signifikan terhadap kinerja pengrajin.

Pengujian pengaruh langsung untuk pengujian koefisien jalur antara kompensasi terhadap kinerja pengrajin sebesar 0,125 , sedangkan pengaruh tidak langsung antara kompensasi melalui motivasi terhadap kinerja pengrajin yaitu $0,171 \times 0,439=-0,075$. Maka berdasarkan hasil perhitungan tersebut dapat diketahui bahwa pengaruh langsung sebesar 0,125 dan pengaruh tidak langsung sebesar -0,171 yang berarti bahwa nilai perhitungan langsung lebih besar dibandingkan pengaruh tidak langsung, hasil ini menunjukkan bahwa secara tidak langsung kompensasi melalui motivasi tidak mempunyai pengaruh signifikan terhadap kinerja pengrajin.

\section{SIMPULAN}

1. Pengendalian internal, Kompensasi dan motivasi secara simultan menunjukkan pengaruh yang signifikan terhadap kinerja pengrajin. 
2. Pengendalian internal berpengaruh positif dan signifikan terhadap motivasi kerja. pengendalian internal yang baik akan memberikan kontribusi baik dalam menciptakan suasana kerja sehingga dapat mendorong karyawan untuk meningkatkan motivasi kerjanya.

3. Kompensasi berpengaruh positif dan tidak signifikan terhadap motivasi, sehingga adanya peningkatan pemberian kompensasi tidak menunjukkan peningkatan terhadap motivasi kerja para pengrajin batik.

4. Pengaruh Pengendalian internal dan Kompensasi secara langsung lebih besar dari pada pengaruh tidak langsung terhadap kinerja melalui motivasi kerja sebagai variabel intervening, sehingga dapat disimpulkan bahwa motivasi kerja tidak menjadi variabel yang memediasi antara pengendalian internal dan kompensasi terhadap kinerja karyawan.

\section{DAFTAR PUSTAKA}

Adisetiawan, R., dan Surono, Yunan., 2011, Analisa Pengaruh Variabel-variabel Fundamental Terhadap Return Saham LQ45, Jurnal Ilmiah Universitas Batanghari Jambi, 11(2), 21-31

Adisetiawan, R., and Surono, Yunan, 2016. Earnings Management and Accounting Information Value: Impact and Relavance, Business, Management and Economics Research, 2(10), 170-179

Alhudhori, M., dan Aldino, W., 2017, Pengaruh Kepemimpinan dan Disiplin Terhadap Motivasi Kerja Serta Dampaknya pada Kinerja Pegawai Rumah Sakit Umum Bersaudara Kabupaten Bungo, JMAS (Jurnal Manajemen dan Sains), 2(1), 23-32

Arens, Alvin A, Randal J Elder \& Mark S. Beasley. 2014, Auditing and Assurance. Services

Agusta, Leonardo dan Eddy Madiono. 2013. Pengaruh Pelatihan dan Motivasi Kerja Terhadap Kinerja Karyawan Pada CV Haragon Surabaya. Jurnal Agora Vol 1 No 3.

Ghozali, Imam, 2011. Aplikasi Analisis Multivariate dengan Program IBM SPSS19. Edisi Kelima. Badan Penerbit Universitas Diponegoro: Semarang

Hasibuan, Malayu SP,. 2010. Manajemen Sumber Daya Manusia. Edisi Revisi, Jakarta : PT Bumi Aksara Idamariyanti. 2011. Batik Jambi. Diakses melalui www.kotajambi.go.id

Jusuf, Haryono., 2014. Auditing. (Pengauditan Berbasis ISA) Penerbit STIE YKPN. Yogyakarta.

Jupran. 2015. Hubungan Kompensasi dengan Motivasi dan Produktivitas Kerja karyawan. Universitas Haluoleo. Diakses melalui jupengchaphathoelhy.blogspot.co.id/2015

Ki Marzuki. 2009. Pengaruh Pengendalian Intern, Sistem Informasi Manajemen dan Kapasitas SDM Terhadap Kinerja Manajerial (Studi Pada Lembaga Keuangan Mikro di Kota Banda Aceh). Universitas Abulyatama Aceh

Luthans, Fred. 2006., Perilaku Organisasi 10th. Edisi Indonesia. Yogyakarta: Penerbit ANDI.

Mariani. 2013. Pengaruh Pengendalian Intern Terhadap Kompensasi dan Kinerja Pada PT. Sinar Galesung Pratama Kendari. Universitas Haluoko

Mulyadi. 2001 Akuntansi Manajemen. Yogyakarta : Penerbit STIE YKPN.

Mangkunegara, Anwar Prabu,. 2015. Evaluasi Kinerja. Bandung: Refika Aditama

Mahesa, Deewar., 2010. Analisis Pengaruh Motivasi dan Kepuasan Kerja Terhadap Kinerja Karyawan dengan Lama Kerja sebagai Variabel Moderating. Undip.

Raf, Mulyadi,. 2012. Analisis Eksplanatori Faktor Daya Saing Industri Kecil (Studi Pada Sentra Industri Kecil Batik di Kota Jambi), Jurnal Manajemen dan Kewirausahaan. Vol 14 No. 2 September 2012. Page 91-101

Sekaran, Uma. 2000. Research Methods For Business: A Skill-Building Approach. Third Edition. New York: John Wiley \& Sons Inc.

Suharto dan Budi Cahyono. 2005, Pengaruh Budaya Organisasi, Kepemimpinan dan Motivasi Kerja Terhadap Kinerja Sumber Daya Manusia, di sekretariat DPRD Propinsi Jawa Tengah, JRBI. Vol. 1, No.1, januari 2005: 13-30

Yuafni. 2012. Faktor-Faktor yang Mempengaruhi Produksi Batik Pada Industri Batik di Kota Jambi. Skripsi. Universitas Negeri Padang.

Whittington, O Ray. \& Pany, Kurt. 2001. Principles of Auditing and Other Assurance Service. $13^{\text {th }}$ Edition, New York: McGraw Hill. 